\title{
High glucose upregulates endothelin type $B$ receptors in vascular smooth muscle cells via the downregulation of Sirt1
}

\author{
YAN LIN $^{1,2}$, YAN ZHAO 3 and ENQI LIU ${ }^{1}$ \\ ${ }^{1}$ Xi'an Jiaotong University Cardiovascular Research Center, Laboratory Animal Center, \\ Xi'an Jiaotong University Health Science Center, Xi'an Jiaotong University, Xi'an, Shaanxi 710061; \\ ${ }^{2}$ Clinical Laboratory, The Hospital of Xi'an Jiaotong University, Xi'an, Shaanxi 710077; ${ }^{3}$ Department of Pathophysiology, \\ School of Basic and Medical Sciences, Xi'an Medical University, Xi'an, Shaanxi 710021, P.R. China
}

Received February 6, 2017; Accepted October 17, 2017

DOI: $10.3892 /$ ijmm.2017.3242

\begin{abstract}
Silent information regulator family protein 1 (Sirt1) has recently gained attention for its protective effects against diabetic and cardiovascular diseases (CVDs). Vascular smooth muscle endothelin type $\mathrm{B}\left(\mathrm{ET}_{\mathrm{B}}\right)$ receptors are involved in the pathogenesis of CVDs and diabetes. The aim of present study was to explore whether Sirt1 is involved in high glucose $(\mathrm{HG})$-mediated regulation of $\mathrm{ET}_{\mathrm{B}}$ receptors in rat superior mesenteric arteries (SMA). The rat SMA segments were cultured in the presence and absence of HG with or without the activator of Sirt1 and specific inhibitor for the extracellular signal-regulated protein kinase 1/2 (ERK1/2) for $24 \mathrm{~h}$. Following organ culture, the contractile responses to sarafotoxin $6 \mathrm{c}$ were studied using a sensitive myograph, and the $\mathrm{ET}_{\mathrm{B}}$ receptor protein expression level was determined using western blotting. The results demonstrated that $\mathrm{HG}$ induced upregulation of $\mathrm{ET}_{\mathrm{B}}$ receptor expression and increased receptor-mediated vasoconstriction in SMA. Resveratrol (Res; a Sirt1 activator) concentration-dependently inhibited the $\mathrm{HG}$-induced upregulation of $\mathrm{ET}_{\mathrm{B}}$ receptor expression and receptor-mediated vasoconstriction. Additionally, these effects could also be abolished by an inhibitor of the ERK1/2 signaling
\end{abstract}

Correspondence to: Professor Enqi Liu, Xi'an Jiaotong University Cardiovascular Research Center, Laboratory Animal Center, Xi'an Jiaotong University Health Science Center, Xi'an Jiaotong University, 76 Yanta West Road, Xi'an, Shaanxi 710061, P.R. China

E-mail: liuenqi@mail.xjtu.edu.cn

Abbreviations: CVDs, cardiovascular diseases; DMEM, Dulbecco's modified Eagle's medium; DMSO, dimethyl sulfoxide; ERK1/2, extracellular signal-regulated protein kinase 1/2; ET-1, endothelin-1; $\mathrm{ET}_{\mathrm{A}}$, endothelin type $\mathrm{A} ; \mathrm{ET}_{\mathrm{B}}$, endothelin type $\mathrm{B}$; $\mathrm{HG}$, high glucose; NAD, nicotinamide adenine dinucleotide; Res, resveratrol; S6c, sarafotoxin 6c; Sirt1, silent information regulator family protein 1; SMA, superior mesenteric arteries; VSMCs, vascular smooth muscle cells

Key words: high glucose, endothelin type B receptor, silent information regulator family protein 1 , extracellular signal-regulated protein kinase $1 / 2$, resveratrol pathway. Furthermore, upregulation of ERK1/2 phosphorylation induced by HG was inhibited by Res. In conclusion, HG upregulated $\mathrm{ET}_{\mathrm{B}}$ receptors by downregulating Sirtl and subsequently activating the ERK1/2 signaling pathways in the organ culture SMA.

\section{Introduction}

Diabetes mellitus is a common metabolic condition with signature high blood glucose. It is associated with increased risk of cardiovascular diseases (CVDs), and cardiovascular complication accounts for $>80 \%$ of diabetic-related mortalities (1). High blood glucose is a major contributor to the development of diabetic cardiovascular complications (2). High glucose (HG) has been indicated to injure vascular endothelial cells and vascular smooth muscle cells (VSMCs), which are associated with the development of CVDs (3-5). It is well established that diabetes-induced vascular dysfunction and remodeling in multiple vascular beds may be related to the activation of the endothelin-1 (ET-1) system (6-8).

ET-1 is a potent vasoconstrictor. The endothelin type $\mathrm{A}\left(\mathrm{ET}_{\mathrm{A}}\right)$ and endothelin type $\mathrm{B}\left(\mathrm{ET}_{\mathrm{B}}\right)$ receptors are two types of $\mathrm{G}$ protein-coupled receptors, and through them, ET-1 induces strong and long-lasting vasoconstriction (9). In healthy arteries, the binding of ET-1 with $\mathrm{ET}_{\mathrm{A}}$ receptors on VSMCs mediates the main part of the vasoconstriction, while the $\mathrm{ET}_{\mathrm{B}}$ receptors are predominantly found on the endothelial cells and mediate vasodilatation $(9,10)$. The $\mathrm{ET}_{\mathrm{B}}$ receptors located on endothelial cells are termed as vasorelaxant $\mathrm{ET}_{\mathrm{B}}$ receptors. However, under pathogenic conditions, the expression of $\mathrm{ET}_{\mathrm{B}}$ receptors is upregulated via transcriptional mechanisms on VSMCs and induce vasoconstriction instead, and these are termed vasoconstrictive $\mathrm{ET}_{\mathrm{B}}$ receptors (11). Previous study has demonstrated that $\mathrm{ET}_{\mathrm{B}}$ receptors were highly expressed on the vascular smooth muscle layer in a diabetic model (8).

Silent information regulator family protein 1 (Sirt1), a prominent member of a family of nicotinamide adenine dinucleotide (NAD)-dependent deacetylases, has been reported to affect a wide range of biological functions involving regulation of metabolism, cell survival and organismal lifespan (12). Accumulating studies have demonstrated that Sirt1 serves a protective role in CVDs $(13,14)$, diabetes and 
its complications $(15,16)$. Diabetes in vivo or HG in vitro may suppress the expression of Sirt1 and its activity in VSMCs (17). Additionally, reduced expression or activity of Sirt1 in VSMCs may contribute to the development of vascular dysfunction and promote vascular aging and CVDs (18). Currently, the underlying molecular mechanisms of this remain unclear.

The present study was designed to determine whether Sirt1 is involved in $\mathrm{HG}$-mediated regulation of $\mathrm{ET}_{\mathrm{B}}$ receptors in the superior mesenteric arteries (SMA) of rats. The present study may identify novel targets for the mechanism of diabetesassociated ischemic CVDs.

\section{Materials and methods}

Chemicals and drugs. Selective $\mathrm{ET}_{\mathrm{B}}$ receptor agonist sarafotoxin 6c (S6c), inhibitor for extracellular signal-regulated protein kinase 1 and 2 (ERK1/2; U0126) and resveratrol (Res; activator of Sirt1), as well as glucose, were obtained from Sigma-Aldrich (Merck KGaA, Darmstadt, Germany). Dulbecco's modified Eagle's medium (DMEM) was obtained from Gibco (Thermo Fisher Scientific, Inc., Waltham, MA, USA). The inhibitor and Res were dissolved in dimethyl sulfoxide (DMSO). The final concentration of DMSO (vehicle) used in the experiments was $1 \mu \mathrm{l} / \mathrm{ml}$, which equals the volume of the inhibitor added to the organ culture. The DMSO concentration was the same in all test conditions, and it was used in the organ culture without the inhibitor to serve as a control. S6c was dissolved in $0.9 \%$ saline with $0.1 \%$ bovine serum albumin (Sigma-Aldrich; Merck KGaA). Glucose was diluted in DMEM just prior to initiation of the experiments.

Tissue preparation and organ culture procedure. A total of 80 male Sprague-Dawley rats (age, 8 weeks; weight, 300-350 g) were obtained from the Laboratory Animal Center of Xi'an Jiaotong University (Xi'an, China). All rats were housed in a temperature-controlled $\left(20 \pm 2^{\circ} \mathrm{C}\right)$ and humidity-controlled (40-70\%) facility on a 12-h light/dark cycle. Rats had free access to food and water. Following euthanasia with $\mathrm{CO}_{2}$, the SMA was gently removed and freed from adhering tissue under a dissecting microscope. The endothelium was denuded by perfusion $\left(4^{\circ} \mathrm{C}\right)$ of the vessel for $10 \mathrm{sec}$ with Triton $\mathrm{X}-100$ $(0.1 \%, \mathrm{v} / \mathrm{v})$ followed by another $10 \mathrm{sec}$ with a physiologic buffer solution $\left(\mathrm{NaCl} 119 \mathrm{mM}, \mathrm{KCl} 4.6 \mathrm{mM}, \mathrm{NaHCO}_{3} 15 \mathrm{mM}\right.$, $\mathrm{NaH}_{2} \mathrm{PO}_{4} 1.2 \mathrm{mM}, \mathrm{MgCl}_{2} 1.2 \mathrm{mM}, \mathrm{CaCl}_{2} 1.5 \mathrm{mM}$ and glucose $5.5 \mathrm{mM})$. The vessels were then cut into $1-3-\mathrm{mm}$ long cylindrical segments and incubated at $37^{\circ} \mathrm{C}$ in a humidified atmosphere of $5 \% \mathrm{CO}_{2}$ and $95 \%$ air in DMEM [containing L-glutamine $(584 \mathrm{mg} / \mathrm{l})$ and normal glucose $(5.5 \mathrm{mM})]$ supplemented with penicillin $(100 \mathrm{U} / \mathrm{ml})$ and streptomycin $(100 \mathrm{mg} / \mathrm{ml})$ (Thermo Fisher Scientific, Inc.) (19,20). To mimic hyperglycemic conditions, the cylindrical segments were exposed for up to $24 \mathrm{~h}$ to $\mathrm{HG}$ (15 or $25 \mathrm{mM}$ ) DMEM (normal DMEM supplemented with $\mathrm{HG}$ concentrations) in a $\mathrm{CO}_{2}(5 \%)$ incubator at $37^{\circ} \mathrm{C}$. Other experiments were performed under similar conditions in the absence/presence of inhibitor [U0126 $(10 \mu \mathrm{M})$ ] or Sirt1 activator [Res $(10,50$ or $100 \mu \mathrm{M})]$, which were added to the medium prior to incubation.

The animal experiments in the present investigation were approved by the Laboratory Animal Administration Committee of Xi'an Jiaotong University and conformed to the Guidelines for Animal Experimentation of Xi'an Jiaotong University (20) and the Guide for the Care and Use of Laboratory Animals published by the US National Institutes of Health [NIH Publication no. 85-23, revised 2011 (21)].

In vitro pharmacology. The present experiments were performed according to a previously published protocol (20). Briefly, fresh or incubated cylindrical artery segments were immersed in temperature-controlled $\left(37^{\circ} \mathrm{C}\right)$ myograph individual baths (Organ Bath Model 700MO; J.P. Trading, Aarhus, Denmark) containing $5 \mathrm{ml}$ physiologic buffer solution. The solution was continuously gassed with $5 \% \mathrm{CO}_{2}$ in $\mathrm{O}_{2}$, resulting in a $\mathrm{pH}$ of 7.4. The cylindrical arterial segments were mounted for continuous recording of isometric tension with LabChart 7 Pro software (ADInstruments, Hastings, UK). A resting tone of $2 \mathrm{mN}$ was applied to each segment, and the segments were allowed to stabilize at this tension for at least $1.5 \mathrm{~h}$ before exposure to a potassium-rich $\left(60 \mathrm{mM} \mathrm{K}^{+}\right)$buffer solution with the same composition as the standard solution, except that $\mathrm{NaCl}$ was replaced by an equimolar concentration of $\mathrm{KCl}$. The potassium-induced contraction was used as a reference for contractile capacity, and the segments were used only if potassium elicited reproducible responses over $1.0 \mathrm{mN}$. Concentration-response curves for S6c, a selective $\mathrm{ET}_{\mathrm{B}}$ receptor agonist $\left(10^{-11}-10^{-7} \mathrm{M}\right)$, were obtained by cumulative administration of the reagent.

Western blotting. Arterial segment lysate preparation and western blot analysis were performed as previously described (20). Briefly, following organ culture for $24 \mathrm{~h}$, the arterial segments were lysed on ice for $1 \mathrm{~h}$ in radioimmunoprecipitation assay buffer [Tris- $\mathrm{HCl}(\mathrm{pH} 8.0) 50 \mathrm{mM}, \mathrm{NaCl}$ $150 \mathrm{mM}, 1 \%$ Triton X-100 (v/v), 1\% deoxycholic acid (w/v) and $0.1 \%$ sodium dodecyl sulfate] containing $0.5 \mathrm{mM}$ phenylmethylsulfonyl fluoride and protease inhibitors (Roche Diagnostics, Basel, Switzerland). Protein concentration was measured with a BCA protein assay kit (Thermo Fisher Scientific, Inc.). After being denatured by boiling for 5 min in Laemmli loading buffer (Beyotime Institute of Biotechnology, Haimen, China), equal amounts of protein $(50 \mu \mathrm{g})$ were loaded and separated on $10 \%$ sodium dodecyl sulfate-polyacrylamide gel electrophoresis (SDS-PAGE) and transferred to polyvinylidene difluoride membranes. To block non-specific binding, the membranes were incubated with $5 \%$ bovine serum albumin or non-fat dried milk for $1 \mathrm{~h}$ at $37^{\circ} \mathrm{C}$. Subsequently, the membranes were incubated with primary antibodies overnight at $4^{\circ} \mathrm{C}$. The primary antibodies contained anti-phospho-p44/42 antibody (1:1,000; 4370; Cell Signaling Technology, Inc., Danvers, MA, USA), anti-p44/42 antibody (1:1,000; ab115799), anti-ET B $_{\text {receptor }}$ antibody (1:1,000; ab65972), anti-Sirt1 antibody (1:1,000; ab104833) and anti- $\beta$-actin antibody $(1: 1,000 ;$ ab8226) (Abcam, Cambridge, MA, USA). After being washed with Tris-buffered saline containing 0.1\% Tween-20 (Beyotime Institute of Biotechnology), the membranes were incubated with horseradish peroxidase-conjugated goat anti-mouse or -rabbit immunoglobulin G (1:1,000; 31430 and 31460; Thermo Fisher Scientific, Inc.) for $1 \mathrm{~h}$ at $37^{\circ} \mathrm{C}$, followed by enhanced chemiluminescence using a SuperSignal West PicoSubstrate kit (Pierce; Thermo Fisher Scientific, Inc.) and analyzed 
A

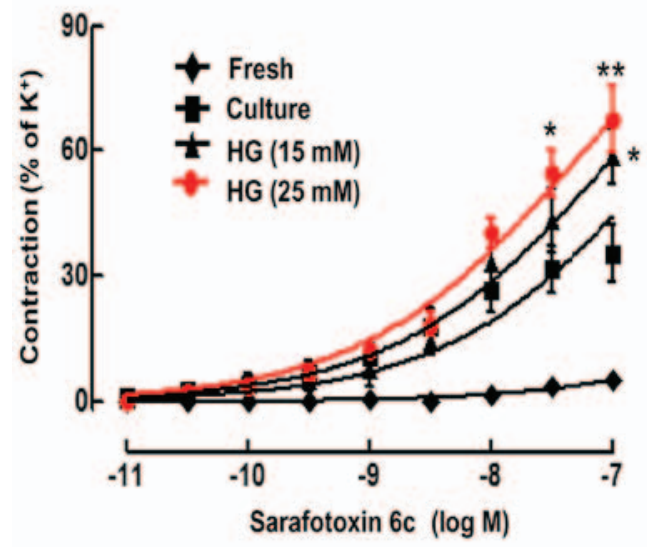

B

$\mathrm{ET}_{\mathrm{B}}$

$\beta$-actin
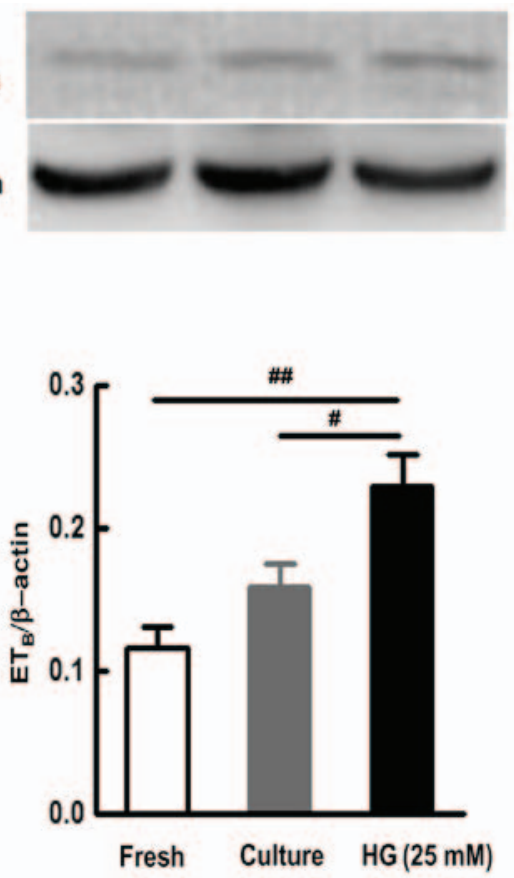

Figure 1. HG increases the receptor-mediated contractile response and $\mathrm{ET}_{\mathrm{B}}$ receptor protein expression. (A) After the rat SMA rings were cultured with different doses of $\mathrm{HG}(15$ or $25 \mathrm{mM})$ for $24 \mathrm{~h}$, the contractile response curves induced by sarafotoxin $6 \mathrm{c}$ were measured and presented as a percentage of $60 \mathrm{mM}$ $\mathrm{K}^{+}$-induced contraction. Data are presented as the mean $\pm \mathrm{SEM}$ ( $\mathrm{n}=6-8$ artery ring segments). (B) $\mathrm{ET}_{\mathrm{B}}$ receptor protein expression levels were detected after $24 \mathrm{~h}$ of organ culture with $\mathrm{HG}(25 \mathrm{mM})$ in SMA without endothelium. Data are presented as the mean $\pm \mathrm{SEM}(\mathrm{n}=3)$. ${ }^{*} \mathrm{P}<0.05$ and ${ }^{* *} \mathrm{P}<0.01$ vs. culture; ${ }^{*} \mathrm{P}<0.05$ and ${ }^{\# \#} \mathrm{P}<0.01$ as indicated. HG, high glucose; $\mathrm{ET}_{\mathrm{B}}$, endothelin type B; SMA, superior mesenteric artery; SEM, standard error of the mean.

using the ChemiDoc-it HR 410 imaging system (UVP, LLC, Phoenix, AZ, USA).

Statistical analysis. All data were expressed as the mean \pm standard error of the mean. S6c-induced vasoconstriction data were presented as a percentage of contraction induced by $60 \mathrm{mM} \mathrm{K}^{+}$. Two sets of data were compared using the unpaired Student's t-test with Welch's correction or two-way analysis of variance (ANOVA) with Bonferroni post hoc test. One-way ANOVA with Dunnett's post hoc test was applied for comparisons of more than two data sets. Data analysis was performed using SPSS version 20.0 (IBM Corp., Armonk, NY, USA). P<0.05 was considered to indicate a statistically significant difference.

\section{Results}

Effects of $H G$ on $E T_{B}$ receptor-mediated vasoconstriction and $E T_{B}$ receptor protein expression in the SMA. In the fresh SMA ring, S6c induced only negligible contractions (Emax value, $5.12 \pm 1.05 \%)$. After organ culture alone for $24 \mathrm{~h}, \mathrm{~S} 6 \mathrm{c}$ induced strong contraction of SMA in a concentrationdependent manner, with an Emax value of $35.38 \pm 6.79 \%$ and a pEC50 value of $6.57 \pm 0.33$. Culture with different doses of HG (15 and $25 \mathrm{mM}$ ) further shifted the S6c-induced concentration-contraction curve of organ culture artery toward the left and significantly increased contractile responses to S6c, with an Emax of $58.46 \pm 6.60 \%$ and pEC50 of $7.31 \pm 0.17$ for $15 \mathrm{mM}$ HG, and an Emax of $67.58 \pm 8.04 \%$ and pEC50 of $7.51 \pm 0.15$ for $25 \mathrm{mM}$ HG, respectively $(\mathrm{P}<0.05)$ (Fig. 1A). This suggests that organ culture enhanced the contraction of the SMA induced by S6c. In addition, $\mathrm{HG}$ further enhanced the $\mathrm{ET}_{\mathrm{B}}$ receptormediated contraction of the SMA induced by S6c.
There were no significant differences in the $\mathrm{K}^{+}$-induced contraction among the groups, and incubation with control in the concentration used did not affect the contractile response to S6c (data not shown).

The SMA segments were cultured for $24 \mathrm{~h}$ in the presence or absence of $\mathrm{HG}(25 \mathrm{mM}) . \mathrm{ET}_{\mathrm{B}}$ receptor protein expression in vascular smooth muscles were assessed using western blotting. The results demonstrated that there were low levels of $\mathrm{ET}_{\mathrm{B}}$ receptor protein in fresh SMA segments. Organ culture alone induced an increase in the $\mathrm{ET}_{\mathrm{B}}$ receptor protein expression level compared to the fresh group; however, this did not achieve statistical significance. Furthermore, HG (25 mM) significantly elevated protein expression levels of $\mathrm{ET}_{\mathrm{B}}$ receptors in cultured SMA segments, compared with the culture alone group $(\mathrm{P}<0.05)$ (Fig. 1B).

Activating Sirtl with Res blocks the HG-increased proteinexpression of $E T_{B}$ receptors and receptor-mediated vasoconstriction in the SMA. Culture with HG and different doses of Res (10, 50 or $100 \mu \mathrm{M}$ ) inhibited the HG-enhanced contractile responses to S6c, and decreased the Emax from 67.03 $\pm 9.27 \%$ in HG-cultured artery to $33.56 \pm 9.87 \%(10 \mu \mathrm{M} ; \mathrm{P}<0.05), 21.95 \pm 4.56 \%(50 \mu \mathrm{M}$; $\mathrm{P}<0.01)$ and $4.32 \pm 0.63 \%(100 \mu \mathrm{M} ; \mathrm{P}<0.01)$ (Fig. $2 \mathrm{~A})$.

$\mathrm{The}_{\mathrm{B}} \mathrm{ET}_{\mathrm{B}}$ receptor protein expression in the SMA following organ culture with Res $(100 \mu \mathrm{M})$ was examined using western blotting. Compared with the control group (culture alone), HG significantly upregulated the levels of $\mathrm{ET}_{\mathrm{B}}$ receptors $(\mathrm{P}<0.01)$ (Fig. 2B). However, Res $(100 \mu \mathrm{M})$ significantly inhibited the HG-induced elevation of the $\mathrm{ET}_{\mathrm{B}}$ receptor protein levels $(\mathrm{P}<0.01)$ (Fig. 2B).

These findings suggest that HG-increased protein expression of $\mathrm{ET}_{\mathrm{B}}$ receptors and receptor-mediated contractile 
A

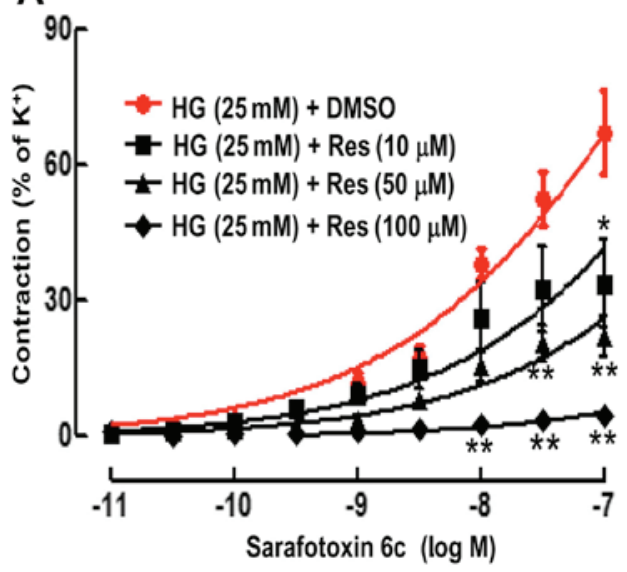

B
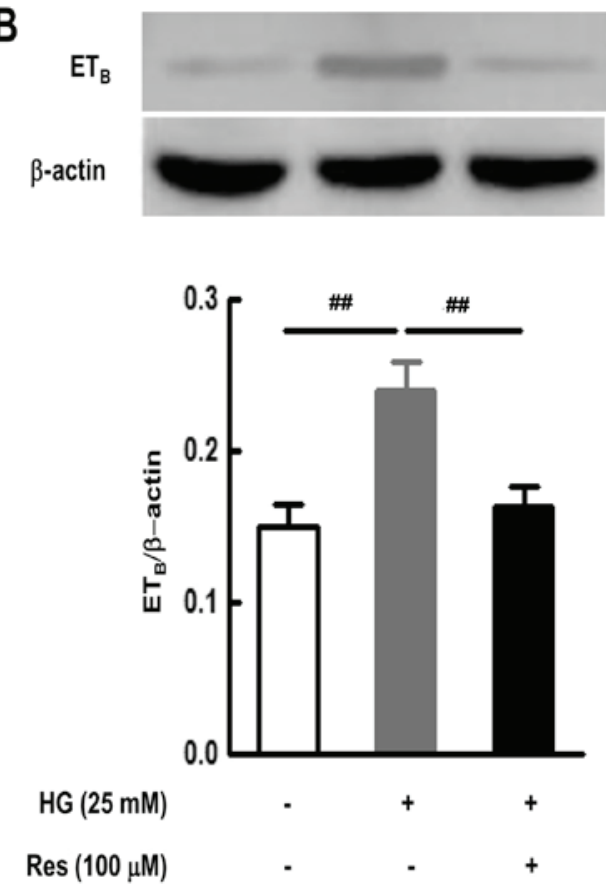

Figure 2. Activating Sirt1 with Res blocks the HG-increased receptor-mediated contractile response and $\mathrm{ET}_{\mathrm{B}}$ receptor expression. (A) After the rat SMA rings were cultured with HG $(25 \mathrm{mM})$ in the presence or absence of different doses of Res $(10,50$ or $100 \mu \mathrm{M})$ for $24 \mathrm{~h}$, the contractile response curves induced by sarafotoxin $6 \mathrm{c}$ were measured and presented as a percentage of $60 \mathrm{mM} \mathrm{K}^{+}$-induced contraction. Data are presented as the mean \pm SEM ( $\mathrm{n}=6-8$ artery ring segments). (B) $\mathrm{ET}_{\mathrm{B}}$ receptor protein expression levels were detected after $24 \mathrm{~h}$ of organ culture with or without $\mathrm{HG}(25 \mathrm{mM})$ in the presence or absence of Res $(100 \mu \mathrm{M})$ in SMA. Data are presented as the mean $\pm \operatorname{SEM}(\mathrm{n}=3) .{ }^{*} \mathrm{P}<0.05$ and ${ }^{* *} \mathrm{P}<0.01$ vs. HG $\pm \mathrm{DMSO}$; ${ }^{\# \#} \mathrm{P}<0.01$ as indicated. Sirt1, silent information regulator family protein 1; Res, resveratrol; $\mathrm{HG}$, high glucose; $\mathrm{ET}_{\mathrm{B}}$, endothelin type B; SMA, superior mesenteric artery; SEM, standard error of the mean; DMSO, dimethyl sulfoxide.

function were related to Sirt1 signaling pathways. Sirt1 activator may effectively inhibit HG-induced upregulation of $\mathrm{ET}_{\mathrm{B}}$ receptor protein expression and receptor-mediated contractile function.

ERKI/2 signaling pathway is involved in the upregulation of $E T_{B}$ receptor protein expression and receptor-mediated vasoconstriction induced by $H G$ in the organ culture SMA. As demonstrated in Fig. 3, culture with $\mathrm{HG}$ and the inhibitor for ERK1/2 (U0126) significantly attenuated the HG-enhanced contractile responses to S6c, and decreased the Emax from $66.89 \pm 8.36 \%$ in HG-cultured artery to $16.44 \pm 5.51 \%$ (P<0.01) (Fig. 3A).

The level of phosphorylated ERK1/2 (p-ERK1/2) and $\mathrm{ET}_{\mathrm{B}}$ receptor protein expression in the SMA were examined following culture with or without $\mathrm{HG}(25 \mathrm{mM})$ in the presence of or absence of U0126. As demonstrated in Fig. 4, the level of p-ERK $1 / 2$ was low in the control group following organ culture for $24 \mathrm{~h}$. Compared with the control group, $\mathrm{HG}(25 \mathrm{mM})$ significantly upregulated the levels of p-ERK1/2 $(\mathrm{P}<0.05)$ (Fig. 4B). However, the inhibitor for ERK1/2 (U0126) significantly reduced the increases in $\mathrm{ET}_{\mathrm{B}}$ receptor protein expression induced by HG ( $\mathrm{P}<0.01)$ (Fig. 3B). Additionally, U0126 almost completely abolished the HG-induced upregulation of $\mathrm{ET}_{\mathrm{B}}$ receptor protein expression in SMA segments (Fig. 3B). These results suggest that $\mathrm{HG}$ activated the ERK1/2 signaling pathway, which resulted in upregulation of $\mathrm{ET}_{\mathrm{B}}$ receptor expression and receptor-mediated contractile function.

Activating Sirtl with Res inhibits the HG-induced activation of ERK1/2 signaling pathways. In order to further study the relationship between Sirt1 and ERK1/2 signaling pathways in HG-cultured rat SMA, Res $(100 \mu \mathrm{M})$ was used for activating Sirt1, and then the level of p-ERK1/2 was detected using western blotting. The results demonstrated that the level of Sirt1 was relatively high in SMA segments following organ culture for $24 \mathrm{~h}$. However, culture with HG significantly decreased Sirtl protein expression compared with the level in culture alone $(\mathrm{P}<0.01)($ Fig. $4 \mathrm{~A})$. Res significantly reversed the decrease in Sirt1 protein expression caused by HG $(\mathrm{P}<0.01)$ (Fig. 4A). In addition, Res also inhibited the increase in the level of p-ERK1/2 induced by HG in SMA segments $(\mathrm{P}<0.01)$ (Fig. 4B). These results indicate that the activation of Sirt1 could inhibit the HG-induced activation of ERK1/2 signaling pathways. Therefore, in the present study, HG upregulated $\mathrm{ET}_{\mathrm{B}}$ receptor expression and the receptormediated contractile response by downregulating the level of Sirt1 and activating the ERK1/2 signaling pathway in SMA (Fig. 5).

\section{Discussion}

The present study investigated the effect of $\mathrm{HG}$ on $\mathrm{ET}_{\mathrm{B}}$ receptor protein expression in VSMCs and its mechanisms. The results suggested that HG enhanced receptor-mediated contractile responses to $\mathrm{S} 6 \mathrm{c}$ and increased the $\mathrm{ET}_{\mathrm{B}}$ receptor protein expression in rat SMA. Meanwhile, the level of Sirt1 was downregulated and the ERK1/2 signaling pathway was activated in the HG-cultured rat SMA. Additionally, the activation of ERK1/2 signaling pathways could be inhibited by Sirt1 activator. This suggested that HG decreased the level 

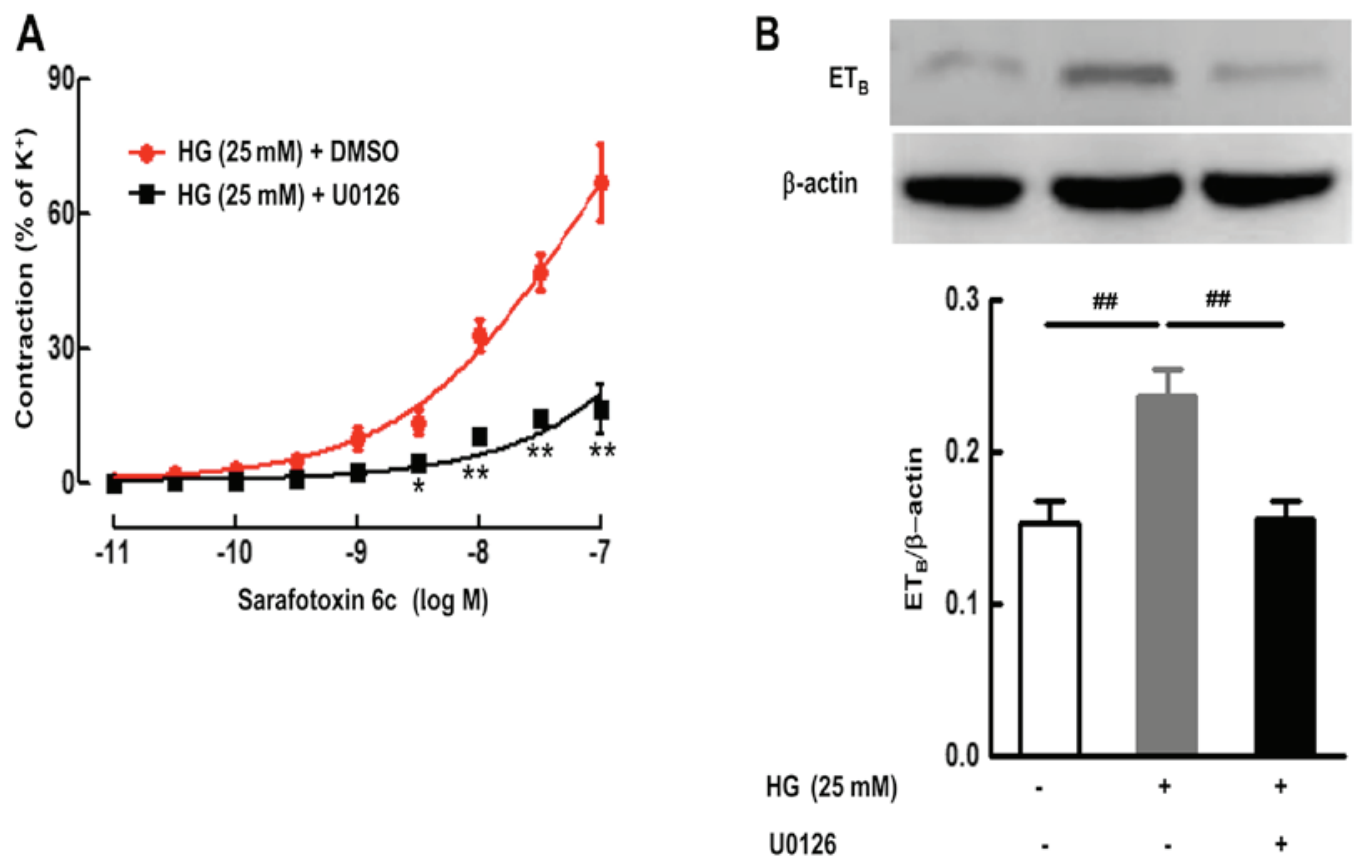

Figure 3. The ERK1/2 signaling pathway is involved in the upregulation of $\mathrm{ET}_{\mathrm{B}}$ receptor protein expression and receptor-mediated vasoconstriction induced by HG. (A) After the rat SMA segments were cultured with HG $(25 \mathrm{mM})$ in the presence or absence of ERK1/2 inhibitor (U0126) for $24 \mathrm{~h}$, the contractile response curves induced by sarafotoxin $6 \mathrm{c}$ were measured and presented as a percentage of $60 \mathrm{mM} \mathrm{K}{ }^{+}$-induced contraction. Data are presented as the mean \pm SEM ( $\mathrm{n}=6-8$ artery ring segments). (B) $\mathrm{ET}_{\mathrm{B}}$ receptor protein expression levels were detected after $24 \mathrm{~h}$ of organ culture with or without $\mathrm{HG}(25 \mathrm{mM})$ in the presence or absence of ERK1/2 inhibitor (U0126) in SMA. Data are presented as the mean \pm SEM ( $=3$ ). ${ }^{*} \mathrm{P}<0.05$ and ${ }^{* *} \mathrm{P}<0.01$ vs. HG \pm DMSO; ${ }^{\# \#} \mathrm{P}<0.01$ as indicated. ERK1/2, extracellular signal-regulated protein kinase 1/2; HG, high glucose; $\mathrm{ET}_{\mathrm{B}}$, endothelin type B; SMA, superior mesenteric artery; SEM, standard error of the mean; DMSO, dimethyl sulfoxide.
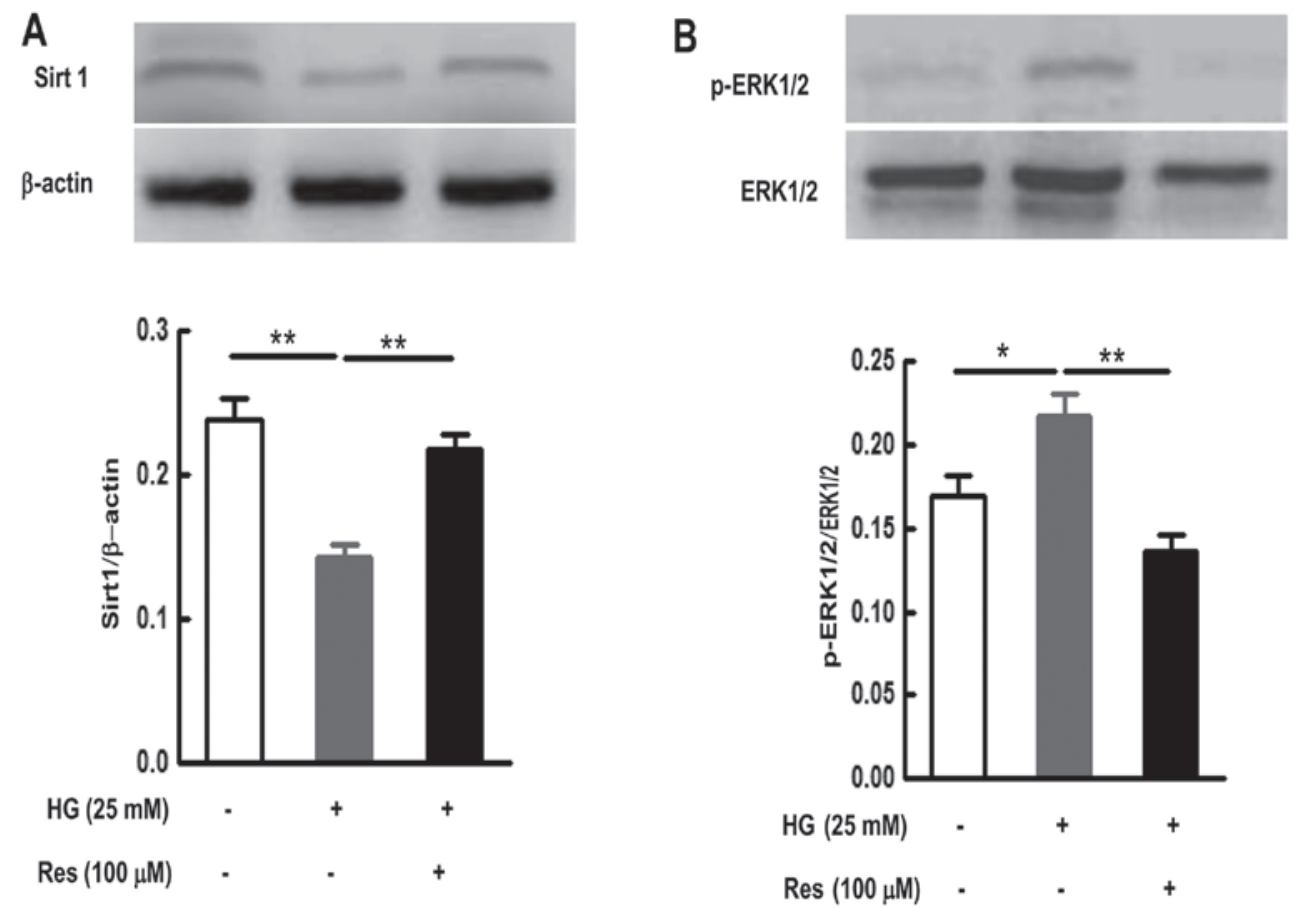

Figure 4. Activating Sirt1 with Res inhibits the HG-induced activation of the ERK1/2 signaling pathways. After the superior mesenteric artery rings were cultured with or without HG $(25 \mathrm{mM})$ in the presence or absence of Res $(100 \mu \mathrm{M})$ for $24 \mathrm{~h}$, the protein expression levels of (A) Sirt1 and (B) p-ERK1/2 were detected. Data are presented as the mean \pm standard error of the mean $(n=3)$. $P<0.05$ and ${ }^{* *} \mathrm{P}<0.01$ as indicated. Sirt1, silent information regulator family protein 1; Res, resveratrol; HG, high glucose; ERK1/2, extracellular signal-regulated protein kinase 1/2; p-, phosphorylated.

of Sirt1 protein and activated the ERK1/2 signaling pathway, which resulted in upregulation of $\mathrm{ET}_{\mathrm{B}}$ receptor protein expression and receptor-mediated vasoconstriction in rat SMA.
Phenotypic modification of VSMCs may occur in physiological and pathophysiological settings, which is the basis of VSMC vasomotion and proliferation (22). Study has 


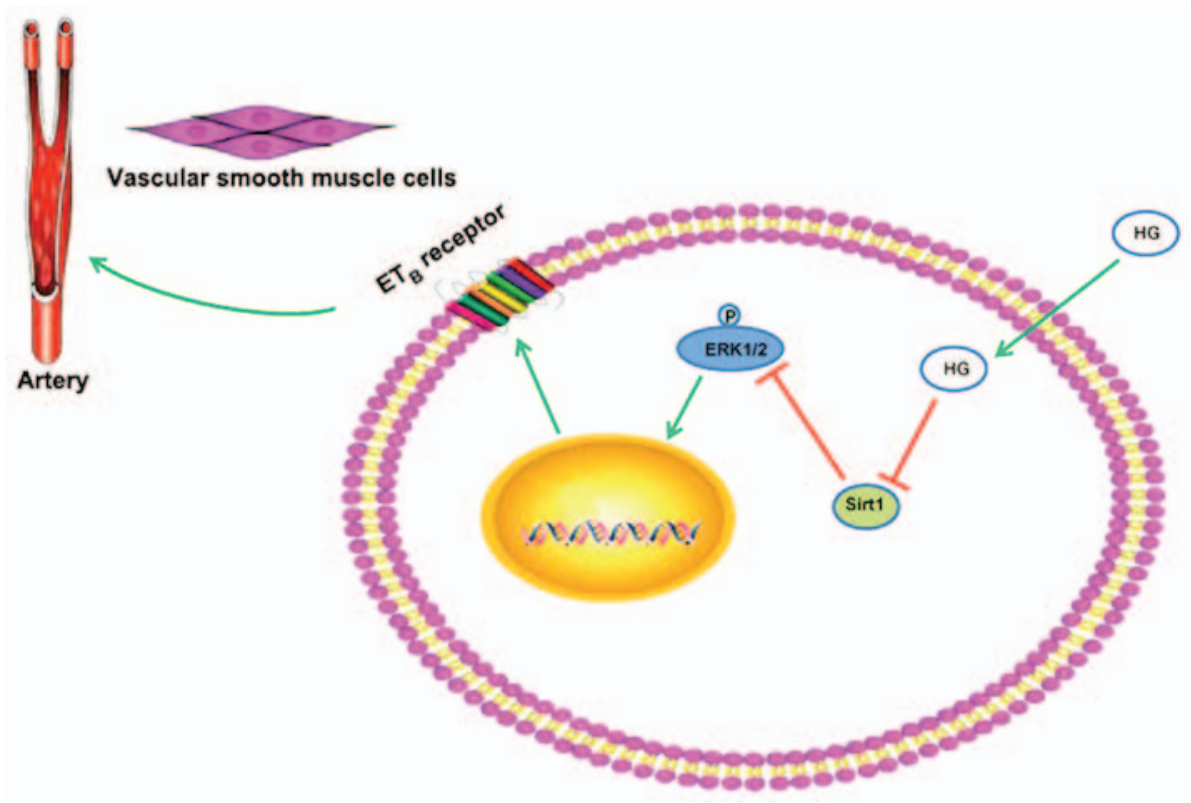

Figure 5. Schematic illustration of the signaling pathway involved in the effect of $\mathrm{HG}$ on $\mathrm{ET}_{\mathrm{B}}$ receptor expression and the receptor-mediated contractile response in rat SMA. HG downregulates the level of Sirt1 and activates the ERK1/2 signaling pathway, and subsequently induces the upregulation of $\mathrm{ET}_{\mathrm{B}}$ receptor expression and the receptor-mediated contractile response in rat SMA. HG, high glucose; $\mathrm{ET}_{\mathrm{B}}$, endothelin type B; SMA, superior mesenteric artery; Sirt1, silent information regulator family protein 1; ERK1/2, extracellular signal-regulated protein kinase 1/2; p-, phosphorylated.

demonstrated that $\mathrm{ET}_{\mathrm{B}}$ receptors were involved in phenotypic modification of VSMCs (11). Organ culture provides a model for exploring the mechanisms involved in upregulation of vascular smooth muscle $\mathrm{ET}_{\mathrm{B}}$ receptors (11). In the present study, organ culture of the SMA was also used as a model to investigate the effect of $\mathrm{HG}$ on $\mathrm{ET}_{\mathrm{B}}$ receptor expression in rat SMA. The present results demonstrated that HG significantly upregulated $\mathrm{ET}_{\mathrm{B}}$ receptor protein expression and the receptor-mediated vasoconstriction induced by $\mathrm{S} 6 \mathrm{c}$ in the organ culture SMA. In endothelial cells, $\mathrm{ET}_{\mathrm{B}}$ receptors mediate vasodilatation via release of nitric oxide and prostacyclin (23). However, $\mathrm{ET}_{\mathrm{B}}$ receptors induce vasoconstriction in VSMCs, which may be related to the phosphatidylinositol 4,5-bisphosphate system (24). In addition, in the present study, the level of Sirt1 in HG-cultured rat SMA was significantly decreased. This suggested that Sirtl may be involved in the process of HG increasing $\mathrm{ET}_{\mathrm{B}}$ receptor expression and the receptor-mediated vasoconstriction in the organ culture SMA.

Sirt1 has been implicated in the process of aging, metabolism and tolerance to oxidative stress (25). In recent years, Sirt1 has been implicated in the pathogenesis of CVDs (26). Additionally, studies have recently identified that Sirt 1 could improve VSMC functions (27) and serve a protective role in CVDs $(13,14)$. Sirt1 deficiency in VSMCs could lead to vascular dysfunction and promote CVDs (18). A study by Badi et al (28) reported that downregulation of Sirt1 by miR-34a in VSMCs promotes senescence and inflammation. Other researchers also agreed that the loss of endogenous Sirt1 protein in human VSMCs directly contributes to the induction of cellular senescence and deficits of cellular function, including an impaired stress response, and reduced capacity for cell migration and proliferation (29). However, diabetes induction in vivo and HG concentrations in vitro significantly downregulated the level of Sirt1 protein in rat VSMCs (17). This finding was also demonstrated in the present study. Sirt1 is a NAD-dependent deacetylase, and it requires NAD for its enzymatic activity (30). Previous study demonstrated that inhibition of NAD biosynthesis may be one of the major mechanisms involved in the downregulation of Sirt1 induced by HG or hyperglycemia (17). In the present study, activating Sirt1 with Res significantly inhibited HG-induced upregulation of $\mathrm{ET}_{\mathrm{B}}$ receptor expression and receptor-mediated vasoconstriction in the organ culture SMA. This suggested that the enhancement of receptor-mediated vasoconstriction and the increase in $\mathrm{ET}_{\mathrm{B}}$ receptor protein expression was related to the downregulation of Sirt1 in HG-cultured rat SMA.

Additionally, the present study demonstrated that the level of p-ERK1/2 was significantly increased in HG-cultured rat SMA segments. ERK1/2 is one of three main signaling pathways of mitogen-activated protein kinases, and it has received attention for its involvement in the regulation of $\mathrm{ET}_{\mathrm{B}}$ receptors in VSMCs (20). Risk factors for CVDs, including cigarette smoke particles (31), minimally modified low-density lipoprotein $(32,33)$, low-density lipoprotein (19) or homocysteine (20), could induce $\mathrm{ET}_{\mathrm{B}}$ receptors to be highly expressed on VSMCs through the ERK1/2 signaling pathway. Notably, when a specific ERK1/2 inhibitor (U0126) was used to block activation of ERK1/2 in the present study, the HG-induced upregulation of $\mathrm{ET}_{\mathrm{B}}$ receptor protein expression and receptormediated vasoconstriction in the organ culture SMA were blocked distinctly. This suggested that HG upregulated receptor-mediated vasoconstriction and $\mathrm{ET}_{\mathrm{B}}$ receptor expression by activating ERK1/2 signaling pathways.

A previous study has demonstrated that Sirt1 overexpression in VSMCs could significantly inhibit angiotensin II-induced VSMC hypertrophy by suppressing phosphorylation of ERK1/2 (34). This suggested that Sirt1 could regulate the activity of the ERK1/2 pathway. In the present study, activating Sirt1 with Res significantly blocked the upregulation of p-ERK induced by HG in the organ culture SMA. This result was in accordance with a previous study, which demonstrated 
that Sirt1 activator (Res) inhibited ERK1/2 phosphorylation in VSMCs (35). In other cells, Sirtl activator partly reversed the ultraviolet B-induced damage on human retinal pigment epithelial cells by inhibiting AKT and ERK phosphorylation (36). Conversely, researchers reported that Sirt1 deletion led to enhanced pro-inflammatory signaling as demonstrated by increased signal transducer and activator of transcription and ERK phosphorylation (37).

In conclusion, the present results indicate that $\mathrm{HG}$ upregulated $\mathrm{ET}_{\mathrm{B}}$ receptor expression through the Sirt1-ERK1/2 signaling pathways in SMA. The upregulation of $\mathrm{ET}_{\mathrm{B}}$ receptor expression could enhance receptor-mediated vascular contractile responses and result in CVDs. The present study may provide novel therapeutic targets for the prevention and treatment of vasospasm and diabetes-associated CVDs.

\section{Acknowledgements}

The present study was supported in part by the Natural Science Foundation of Shaanxi Province (grant no. 2014PT013) and the Science and Technological Project of Shaanxi Province (grant no. 2016JQ8043).

\section{References}

1. Amos AF, McCarty DJ and Zimmet P: The rising global burden of diabetes and its complications: Estimates and projections to the year 2010. Diabet Med 14 (Suppl 5): S1-S85, 1997.

2. Massi-Benedetti M and Federici MO: Cardiovascular risk factors in type 2 diabetes: The role of hyperglycaemia. Exp Clin Endocrinol Diabetes 107 (Suppl 4): S120-S123, 1999.

3. Zhu ZX, Cai WH, Wang T, Ye HB, Zhu YT, Chi LS, Duan YM, Sun CC, Xuan YH and Jin LT: bFGF-regulating MAPKs are Involved in high glucose-mediated ROS production and delay of vascular endothelial cell migration. PLoS One 10: e0144495, 2015.

4. Zhu L, Sun G, Zhang H, Zhang Y, Chen X, Jiang X, Jiang X, Krauss S, Zhang J, Xiang Y, et al: PGC-1alpha is a key regulator of glucose-induced proliferation and migration in vascular smooth muscle cells. PLoS One 4: e4182, 2009.

5. Yan JY, Zhou Q, Yu HM, Hou ML and Lu LH: High glucose promotes vascular smooth muscle cell calcification by activating WNT signaling pathway. Nan Fang Yi Ke Da Xue Xue Bao 35: 29-33, 2015 (In Chinese)

6. Abdelsaid M, Kaczmarek J, Coucha M and Ergul A: Dual endothelin receptor antagonism with bosentan reverses established vascular remodeling and dysfunctional angiogenesis in diabetic rats: Relevance to glycemic control. Life Sci 118: 268-273, 2014.

7. Khan ZA and Chakrabarti S: Endothelins in chronic diabetic complications. Can J Physiol Pharmacol 81: 622-634, 2003.

8. Kelly-Cobbs AI,Harris AK,Elgebaly MM,LiW,Sachidanandam K, Portik-Dobos V, Johnson M and Ergul A: Endothelial endothelin B receptor-mediated prevention of cerebrovascular remodeling is attenuated in diabetes because of up-regulation of smooth muscle endothelin receptors. J Pharmacol Exp Ther 337: 9-15, 2011.

9. Davenport AP, Hyndman KA, Dhaun N, Southan C, Kohan DE, Pollock JS, Pollock DM, Webb DJ and Maguire JJ: Endothelin. Pharmacol Rev 68: 357-418, 2016.

10. Schneider MP, Boesen EI and Pollock DM: Contrasting actions of endothelin $\mathrm{ET}_{\mathrm{A}}$ and $\mathrm{ET}_{\mathrm{B}}$ receptors in cardiovascular disease Annu Rev Pharmacol Toxicol 47: 731-759, 2007.

11. Xu CB, Sun Y and Edvinsson L: Cardiovascular risk factors regulate the expression of vascular endothelin receptors. Pharmacol Ther 127: 148-155, 2010.

12. Suzuki M and Bartlett JD: Sirtuin1 and autophagy protect cells from fluoride-induced cell stress. Biochim Biophys Acta 1842: 245-255, 2014.

13. Ma L and Li Y: SIRT1: Role in cardiovascular biology. Clin Chim Acta 440: 8-15, 2015.

14. Winnik S, Auwerx J, Sinclair DA and Matter CM: Protective effects of sirtuins in cardiovascular diseases: From bench to bedside. Eur Heart J 36: 3404-3412, 2015.
15. Kitada M and Koya D: SIRT1 in type 2 diabetes: Mechanisms and therapeutic potential. Diabetes Metab J 37: 315-325, 2013.

16. Guo R, Liu W, Liu B, Zhang B, Li W and Xu Y: SIRT1 suppresses cardiomyocyte apoptosis in diabetic cardiomyopathy: An insight into endoplasmic reticulum stress response mechanism. Int $\mathbf{J}$ Cardiol 191: 36-45, 2015.

17. Toniolo A, Warden EA, Nassi A, Cignarella A and Bolego C: Regulation of SIRT1 in vascular smooth muscle cells from streptozotocin-diabetic rats. PLoS One 8: e65666, 2013.

18. Kitada M, Ogura Y and Koya D: The protective role of Sirt1 in vascular tissue: Its relationship to vascular aging and atherosclerosis. Aging (Albany NY) 8: 2290-2307, 2016.

19. Xu CB, Zheng JP, Zhang W, Liu E, Edvinsson L and Zhang Y: Low density lipoprotein induces upregulation of vasoconstrictive endothelin type B receptor expression. Vascul Pharmacol 60: 42-48, 2014.

20. Chen Y, Zhang H, Liu E, Xu CB and Zhang Y: Homocysteine regulates endothelin type $B$ receptors in vascular smooth muscle cells. Vascul Pharmacol 87: 100-109, 2016.

21. Li Y, Zhao S, Wang Y, Chen Y, Lin Y, Zhu N, Zheng H, Wu M, Cheng D, Li Y, et al: Urotensin II promotes atherosclerosis in cholesterol-fed rabbits. PLoS One 9: e95089, 2014.

22. Majesky MW: Developmental basis of vascular smooth muscle diversity. Arterioscler Thromb Vasc Biol 27: 1248-1258, 2007.

23. D'Orléans-Juste P, Labonté J, Bkaily G, Choufani S, Plante M and Honoré JC: Function of the endothelin(B) receptor in cardiovascular physiology and pathophysiology. Pharmacol Ther 95: 221-238, 2002.

24. Ivey ME, Osman N and Little PJ: Endothelin-1 signalling in vascular smooth muscle: Pathways controlling cellular functions associated with atherosclerosis. Atherosclerosis 199: 237-247, 2008.

25. Feige JN and Auwerx J: Transcriptional targets of sirtuins in the coordination of mammalian physiology. Curr Opin Cell Biol 20: 303-309, 2008

26. Matsushima S and Sadoshima J: The role of sirtuins in cardiac disease. Am J Physiol Heart Circ Physiol 309: H1375-H1389, 2015.

27. Zhang MJ, Zhou Y, Chen L, Wang X, Long CY, Pi Y, Gao CY, Li JC and Zhang LL: SIRT1 improves VSMC functions in atherosclerosis. Prog Biophys Mol Biol 121: 11-15, 2016.

28. Badi I, Burba I, Ruggeri C, Zeni F, Bertolotti M, Scopece A, Pompilio G and Raucci A: MicroRNA-34a induces vascular smooth muscle cells senescence by SIRT1 downregulation and promotes the expression of age-associated pro-inflammatory secretory factors. J Gerontol A Biol Sci Med Sci 70: 1304-1311, 2015.

29. Thompson AM, Wagner R and Rzucidlo EM: Age-related loss of SirT1 expression results in dysregulated human vascular smooth muscle cell function. Am J Physiol Heart Circ Physiol 307: H533-H541, 2014.

30. Imai S, Armstrong CM, Kaeberlein M and Guarente L: Transcriptional silencing and longevity protein Sir2 is an NAD-dependent histone deacetylase. Nature 403: 795-800, 2000.

31. Xu CB, Zheng JP, Zhang W, Zhang Y and Edvinsson L: Lipid-soluble smoke particles upregulate vascular smooth muscle $\mathrm{ET}_{\mathrm{B}}$ receptors via activation of mitogen-activating protein kinases and NF-kappaB pathways. Toxicol Sci 106: 546-555, 2008.

32. Jie L, Yong-Xiao C, Zu-Yi Y and Cang-Bao X: Minimally modified LDL upregulates endothelin type $\mathrm{B}$ receptors in rat coronary artery via ERK1/2 MAPK and NF- $\kappa \mathrm{B}$ pathways. Biochim Biophys Acta 1821: 582-589, 2012.

33. Li J, Cao YX, Liu Y and Xu CB: Minimally modified LDL upregulates endothelin type B receptors in rat basilar artery. Microvasc Res 83: 178-184, 2012.

34. Li L, Gao P, Zhang H, Chen H, Zheng W, Lv X, Xu T, Wei Y, Liu D and Liang C: SIRT1 inhibits angiotensin II-induced vascular smooth muscle cell hypertrophy. Acta Biochim Biophys Sin (Shanghai) 43: 103-109, 2011.

35. Miyazaki R, Ichiki T, Hashimoto T, Inanaga K, Imayama I, Sadoshima J and Sunagawa K: SIRT1, a longevity gene, downregulates angiotensin II type 1 receptor expression in vascular smooth muscle cells. Arterioscler Thromb Vasc Biol 28: 1263-1269, 2008 .

36. Chou WW, Chen KC, Wang YS, Wang JY, Liang CL and Juo SH: The role of SIRT1/AKT/ERK pathway in ultraviolet B induced damage on human retinal pigment epithelial cells. Toxicol In Vitro 27: 1728-1736, 2013.

37. Gao R, Chen J, Hu Y, Li Z, Wang S, Shetty S and Fu J: Sirt1 deletion leads to enhanced inflammation and aggravates endotoxin-induced acute kidney injury. PLoS One 9: e98909, 2014. 